\title{
Transformation of Teacher's Body As Students' Learning Medium at Non-Traditional Choreography Lesson in Malang, East Java
}

\section{(Transformasi 'Tubuh' Guru Sebagai Media Belajar Siswa Pada Mata Pelajaran Koreografi Non-Tradisi Di Malang Jawa Timur)}

\section{Dr. Robby Hidajat, M.Sn}

Lecturing Staff at Study Program of Dance and Music Arts Education, Department of Art and Design, Faculty of Letters, Malang State University

\section{Abstract}

Corresponding Author: Dr. Robby Hidajat, M.Sn robby.hidajat.fs@um.ac.id

Received: 17 February 2020 Accepted: 20 February 2020 Published: 27 February 2020

Publishing services provided by Knowledge E

(c) Dr. Robby Hidajat, M.Sn. This article is distributed under the terms of the Creative Commons Attribution License, which permits unrestricted use and redistribution provided that the original author and source are credited.

Selection and Peer-review under the responsibility of the Isolec Conference Committee.
Research is focused on topic concerning non-traditional (contemporary) choreography learning medium. Actually, this topic is still problematic because in one hand, teacher is positioned as facilitator but in the other hand, teacher is used as learning medium. Many assumptions have been provided to solve this problem. Assumptions are invisible and therefore, giving less controversy. This research attempts to review education phenomenology by deriving information from some experiencing dance art teachers. This approach explores problems behind contemporary choreography, which is in this research functioned as body-oriented learning process. Method of research is using qualitative descriptive that applies symbolic interactional theory. Main data are explored by observing actions of teachers during teaching-learning activity while the remaining is obtained through interview. Data analysis technique is interpretative semiotic. Result of research is explained in several sentences. Human body is basically not neutral because it is already affected by culture and local values that shape human's personal characteristic and their method in expressing ideas. However, in teaching dance, body is needed as learning medium and therefore, quality of the body becomes important reference because dance activity is actually the expression of subjectivity. Contemporary choreography requires students not only to understand the body as a potential but also to be sensitive to the actual meaning of reality. Teacher's body helps students to be aware with how to adapt with the current days, to improve selfexpression quality, and to determine which part of the body that is already skilled. Learning contemporary choreography has allowed students to recognize which body part has potentials of being sensitive, interactive, and responsive to social reality. Ringkasan

Penelitian ini memfokuskan pada media belajar koreografi non-tradisi (kontemporer). Topik itu masih jadi problematika, satu sisi menempatkan guru sebagai fasilitator, sisi yang lain, guru adalah sebagai media belajar. Berbagai asumsi memecahkan problematika tersebut, karena asumsi itu tidak tampak di lapangan tidak tampak kontroversinya. Tulisan ini mengkaji fenomenologi pendidikan, pendekatan yang 
menekankan pada pengalaman guru seni tari. pendekatan yang mencoba mengeskplorasi problematika koreografi kontemporer yang difungsikan sebagai proses pembelajaran berorentasi tubuh. Metode penelitian ini menggunakan diskriptif kualitatif yang menerapkan teori intraksional simbolik, data utama yang digali adalah tindakan guru dalam kegiatan belajar mengajar, selebihnya dilakukan wawancara. Analisis data menggunakan semiotika interpertatif. Hasil penelitian memberikan sumbangan pemikiran bahwa: Tubuh manusia pada dasarnya tidak netral, karena telah dimuati oleh budaya dan nilai-nilai lokal yang telah membentuk karakteristik dan cara orang mengungkapkan gagasan. Ketubuhan ini menjadi orientasi sebagai media belajar, sehingga kualitas tubuh menjadi acuan, artinya aktivitas 'tari' itu sebagai ekspresi hasil belajar seni tari juga memuat asp-ek subjektfitas. Koreografi kontemporer untuk pembelajaran membelajarkan tubuh menjadi potensial dan sensitif dalam memahami makna realitas yang aktual. Temuan penelitian, tubuh guru membangun kesadaran tentang kondisi saat ini yang mengalami kondisi kekinian, kualitas mengekspresikan diri, dan menyadari tubuh yang terampil. Pencapaian penelitian adalah hasil pembelajaran koreografi kontemporer yang menunjukan potensi tubuh yang mampu sensitif, interaktif, dan responsif terhadap realitas sosial.

Keywords: choreography, education, contemporary, body

Katakunci: koreografi, pendidikan, kontemporer, tubuh

\section{Background}

State and private junior high schools in Malang City have been counted as 133. Among them are 26 state junior high schools. All these state schools provide dance art as extracurricular activity. Constitutional objective of this activity is to develop students' potentials and interests. However, all schools have been oriented toward practical either for inherent environment of schools or for competition (contest).

In 1992-1996, researcher was once non-official dance art teacher for a private junior high school. Dance was learnt to fill up the slot in school parting event. There was no idealist target other than preparing a dance performance to cheer up the procession of graduation. Such flexible turnaround must be interesting for deep exploration because dance teacher is not in a position to teach standard or base of the dance. 
Research is focused on non-traditional (contemporary) choreography learning medium. However, this topic is still problematic because in one hand, teacher is presumed as facilitator in student learning but in the other hand, teacher is used as learning medium. Many assumptions have been proposed to solve this problem. Problem solving capacity of each assumption is examined on the field, precisely during dance teaching-learning activities.

\section{Method}

This research reviews the phenomenology of dance art teaching at junior high schools in Malang City, East Java. Phenomenological research usually emphasizes on empirical experiences (Sutiyono, 2011:1), which in this research is the occurence of dance teachinglearning activities. Research subject is three teachers who teach dance art at state and private junior high schools, and their names are confidential. Reason behind this confidentiality is because they do not know if they are under observation. Without asking for consent for observation, at least researcher wants to keep their answers in objectivity and honesty. Three teachers were observed more or less in a year, and they include: (1) Galuh, female, 57 years old, teaching at SMAK Frateran, (2) Panji, male, 25 years old, teaching at SMPN 25, and (3) Sekar, female, 29 years old, teaching at SMP Sang Timur. Each has different posture. Different physic and age, therefore, become main indicators of research problems, which are described as: (a) Is teacher's body affecting student's learning result? and (b) How teacher's body can construct dance moves as sudent's learning result?

Symbolic interaction approach is a science that discusses human behavior (Soeprapto, 2002:139). This approach is considered suitable to review actions done by dance art teacher on students during contemporary choreography teaching-learning activities. Teacher action is observed through "body factor", which in this context, is considered as teaching model. Researcher conducted observation to understand teacher performance. Interview was done to get information about technical matters. In-depth observation was reserved to develop specific communication between insider and outsider (Nakagawa, 2000:12). In this research, it is done by observing teacher performance based on teacher's body as learning medium to understand transformation of moves in dance art learning.

Data analysis technique is semiotic interpretation in which data that suppose to be interpreted are something perceived as having meanings (Kurniawan, 2018:243). Data in this research are teacher's attitude and action and result of teaching. 
Synchronic and diachronic comparisons are applied by comparing backgrounds of experience, education and environment where teacher belongs to. In this research, the way of three teachers in scrutinizing students' presentation or performance of their learning results is compared one to another. Result of this comparison shows that dance art teachers who teach non-traditional choreography are greatly affected by (1) backgrounds of education and experience, (2) learning technique and teaching materials, and (3) awareness that body can be functioned as teaching medium.

\section{Data Description}

Non-traditional dance is synonymous with contemporary dance (Hidajat, 2019:105). Dance teaching-learning activities are observed intensively by putting attention on three teachers and their differences. One is male teacher who is $176 \mathrm{~cm}$ height, $57 \mathrm{~kg}$ weight, with upright torso, muscular firm, and strong impression. Other is two female teachers. One is $157 \mathrm{~cm}$ height, $60 \mathrm{~kg}$ weight, and fat but stacked and adept. Another is $168 \mathrm{~cm}$ height, $50 \mathrm{~kg}$ weight, and slender but stacked and agile. Each has different body shape, but each has standard kinetical characteristic as dance teacher.

\subsection{Experience and Education}

Galuh was holding a degree in dance (First Strata) and a diploma in teaching (Fourth Certification), which she believed that it shall be useful for her professional development. Her teaching experience started in 1980s and she did teaching at various institutions including kindergarten, elementary school, junior and senior high schools, and dance club, or sometimes working as choreographer. Panji got his dance experience from dance club. His dance is mostly theatrical at first but it inspires him to take study program in dance art teaching. His teaching experience began since his active presence as instructor in a theater club in 2014. He said that teaching is not his main goal, but he admitted that he needs a medium to express his experience as dancer and choreographer. Sekar was graduated from department of dance art teaching. Her dance experience is quite plenty, mainly in pop dance. Her teaching experience began since she was still student in college, precisely in 2007. She declared that teaching is a way to develop profession, and later, she attained her position as extra-curricular teacher for dance.

Research conducts an observation on dance art teachers at schools in Malang, East Java. The schools observed are located in Malang City and Malang Regency. However, 
school location is not considered as key variable that affects the result because research focus is given upon the meaning of teacher's action in teaching and learning activities and the results of learning presented by students.

Informants' experience is sorted with criteria. They must have profession in dance art, have experience of 2 years minimally in teaching dance art, and have experiences as regular dancer and choreographer. These base criteria are used to determine that informants are really mastering their profession. Some independent variables are used and each has almost same quality in explaining the criteria. These variables are body posture, body weight, material orientation, and teaching technique. Body has been used as teaching technique in different way. Students' learning results are understood through body construction as learning result.

\subsection{Learning Technique and Dance Moves Materials}

All teachers have different orientation in learning technique and dance moves material. Each teacher will be explained in words. (1) Galuh uses instructional learning technique when she teaches dance art at SMAK Frateran. After she invents a dance moves and fixes it, she plays her body on certain pattern but still in manner of visually abreasted with. When students get their turn to follow her move, she uses words to transform early moves into the proper moves. Galuh counts students' moves to obtain precision in moves coverage, foot step, hand height, body position, and speed. For some of her moves, she takes inspiration from ballet impression, especially when the moves involve extending, lifting and spinning hands and legs. The capability of students' body to follow instruction becomes references of overall moves technique. (2) Panji is a dance teacher at SMP N 25 and using imitation learning technique in his teaching. Through this technique, he explores students' moves ability, fixes the moves based on exploration, and uses his body as medium of narration. (3) Sekar uses imitation learning technique in her teaching at SMP Sang Timur. Her teaching material is stressed upon pop dances.

\subsection{Body Function as Teaching Medium}

Basically, human body is not neutral because it contains culture and local values that shape human's personal characteristic and their way of idea expression. When body is used as learning medium, therefore, quality of this body becomes key indicator whether students can learn the lesson or not. As previously said, three teachers observed in this research have different body shape and body quality. Each teacher has different 
strategy to transform ideas into moves that later can be mastered by students. Galuh has realized that her body quality is not the ideal one to be imitated by students. She uses her body only to be "the outline of the move". Therefore, she achieves her ideal quality through instructional guidances. The goal of the instruction is to actualize the impression of ballet moves pattern forged through hand stretch, leg extension, jump and spin. This effort has been successful in making students to be the active audiences. Panji has a firm, strong and flexible body. Such qualities grant him an ideal body to be a model for his students but not for body shape transfer. Students are actuated to search for their own capability. The aim of this actuation is "to make the body to speak". As the consequence, natural moves become more visible than energized moves. Panji wants to bring the body into narrative situation. Ideas of moves are assumed to be able to represent "words" that shall be presented as medium of idea expression. Panji creates a learning situation that can stimulate students to identify pattern and explore possibilities. Imagination, therefore, is emphasized more. Freedom to actuate the body is like a way to seek various possibilities of space and time. Sekar has an ideal body as a dancer. Her ideal body allows her to transform moves pattern easily. Students are required to give attention to the moves shown to them, including foot step, hand rotation, face turning, foot rhythm, and variation of hand moves, which among others is intersecting hands alternately. Moves pattern shown to the students shall allow students to imitate. Words are used only to require students to watch, put attention, and imitate the moves. Such learning situation shall help students to be more focused and more concentrated in understanding moves model. It is hoped that students will compete one to another to duplicate their teacher's body.

\section{Discussion}

Non-traditional (contemporary) choreography is a learning material in dance art lesson at junior high schools in Malang City. This learning material is served to condition teacher's body in order to build awareness about current conditions dealt by students, self-expression quality, and skilled body.

Three models of non-traditional choreography have been analyzed, and the results are elaborated in the following.

1. Teacher's body helps audiences to build awareness about the actual current conditions. Panji has perceived that body pattern reflects an experience about the actuality. Students are encouraged to know their own body and make it talk about something that they feel, sense, and comprehend, especially when 
they must understand their own strength and weakness. This learning technique prevents students from seeing their body as a tool, but as an actual reality. The choreography presented in this research is one that involves a group of dancers who must have internal bonding one to another. The choreography is not telling "texts" but showing something experienced, felt, and wanted to explain by the dancers. Learning result expected by Panji is rejection against exploiting the body as "a tool". Students' body must be presented as what it is with all its strengths and weaknesses. If audiences can recognize the actual conditions and situations of students' body, including all its strengths and weaknesses, thus there shall be no idealistic aesthetics. Audiences are not the separate part of performance, but they are indeed the constituent of a unity called "reality". Body, therefore, is not a medium for expression but a medium to present new reality. Any moves in choreography are always played within performing art realm. The desired aesthetical actualization is to have audiences not only sensing the beauty of dance, but also arousing their empathy to feel their body moving as the performers do. The expected artistical achievement is to have audiences building the feel of their own body.

2. Teacher's body helps audiences to develop awareness about their body quality and their capability to express ideas. This strategy was used by Galuh. Students are brought to consider their body as a medium to learn sensory capacity. Learning dance is meant as activating all potentials of body and mind. The expected learning result is the change of attitude and action from "not comprehend" into "comprehend". At comprehend stage, students can exploit their potentials with their own capacity. Learning result may not same but it will be rather different based on potentials of each student. When students reach their artistical stage, it can be said that they have attained a stage of body comprehension (wiraga rasa).

3. Teacher's body guides audiences to establish awareness about the goal of dance learning. Body is considered a tool to produce moves and the expected learning result is dance skill. Indeed, students are conditioned to use body as a tool of self-presentation. Artistical characteristics of this conditioning are instrumental, formalistic, and with emphasis on rhythmical body (wirama raga). In other words, body can do self-expression through comprehended moval skill. 


\section{Conclusion}

Teacher's body is a potential medium of teaching. However, it has different orientation due to different physical conditions, which in this context, physicality is affected by body posture, body weight and body moving skill. Teacher's body can also determine cultural and local values. Even, it has material orientation, especially when teacher must manipulate the body to develop communication with students during teachinglearning activities. Overall, research indicates that contemporary choreography learning can open students' mind to aware about their body potentials that later can be used to comprehend social reality by being sensitive and responsive to it.

\section{Acknowledgment}

This article is completed through the accumulation of contributions of many individuals who willingly spare times to help the author, such as the author's lecturer colleagues at Study Program of Dance and Music Arts Education, students, and also related alumni. Huge appreciation is given to teachers who still work as usual despite confidential observation. Special gratitude, therefore, shall be extended to Galuh, Panji and Sekar for their supportive information to this article.

\section{References}

[1] Sutiyono. 2011. Art Phenomenology: Observing Social Phenomena in Art. Yogyakarta: Insan Persada.

[2] Nakagawa, Shin. 2000. Music and Cosmos. Jakarta: Yayasan Obor Indonesia.

[3] Soeprapto, H.R.Riyadi. 2002. Symbolic Interactionism. Yogyakarta: Pustaka Pelajar.

[4] Kurniawan, Asep. 2018. Methodology of Education Research. Bandung: Rosdakarya.

[5] Hidajat, Robby. 2019. Education Dance: Dance Art Teaching for Education. Yogyakarta: Media Kreativa. 